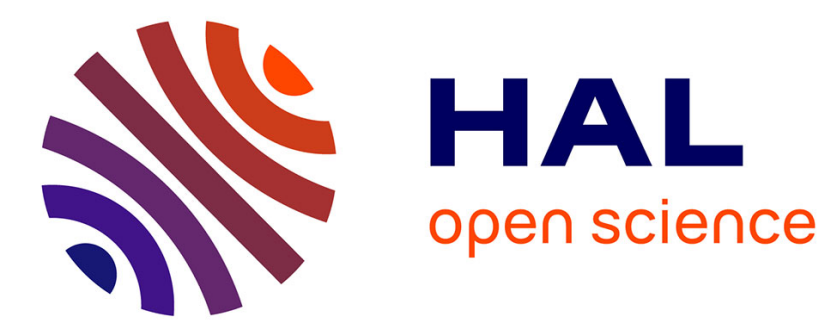

\title{
Thienopyrazine-based low-bandgap polymers for flexible polymer solar cells
}

\author{
S. Sensfuss, L. Blankenburg, H. Schache, S. Shokhovets, T. Erb, A. Konkin,
} A. Herasimovich, S. Scheinert, M. Shahid, S. Sell, et al.

\section{- To cite this version:}

S. Sensfuss, L. Blankenburg, H. Schache, S. Shokhovets, T. Erb, et al.. Thienopyrazine-based lowbandgap polymers for flexible polymer solar cells. European Physical Journal: Applied Physics, 2010, 51 (3), pp.33204. 10.1051/epjap/2010103 . hal-00618494

\section{HAL Id: hal-00618494 \\ https://hal.science/hal-00618494}

Submitted on 2 Sep 2011

HAL is a multi-disciplinary open access archive for the deposit and dissemination of scientific research documents, whether they are published or not. The documents may come from teaching and research institutions in France or abroad, or from public or private research centers.
L'archive ouverte pluridisciplinaire HAL, est destinée au dépôt et à la diffusion de documents scientifiques de niveau recherche, publiés ou non, émanant des établissements d'enseignement et de recherche français ou étrangers, des laboratoires publics ou privés. 


\title{
Thienopyrazine-based Low-Bandgap Polymers for Flexible Polymer Solar Cells
}

\author{
S. Sensfuss ${ }^{1 *}$; L. Blankenburg ${ }^{1}$, H. Schache ${ }^{1}$, S. Shokhovets ${ }^{2}$, T. Erb ${ }^{2}$, A. Konkin ${ }^{3}$, A. Herasimovich ${ }^{4}$, S. Scheinert ${ }^{4}$, M.

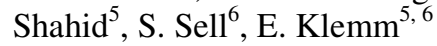 \\ ${ }^{1}$ Dept. Functional Polymer Systems and Physical Research, TITK Research Institute, Breitscheidstr. 97, D-07407 \\ Rudolstadt, Germany, *e-mail: sensfuss@ titk.de \\ ${ }^{2}$ Ilmenau Technical University, Institute for Physics, Weimarer Str.32, D-98684 Ilmenau, Germany \\ ${ }^{3}$ TU Ilmenau, Center for Micro- and Nanotechnologies, Gustav-Kirchhoff-Str.7, D-98693 Ilmenau, Germany \\ ${ }^{4}$ TU Ilmenau, Institute of Solid State Electronics, PF 100565 D-98684 Ilmenau, Germany \\ ${ }^{5}$ Friedrich-Schiller-University of Jena, Institute for Organic Chemistry and Macromolecular Chemistry, Humboldt- \\ str.10, D-07743 Jena, Germany \\ ${ }^{6}$ Jenpolymer Materials Ltd. \& Co. KG, Wildenbruchstr.15, D-07745 Jena, Germany
}

\begin{abstract}
The optical gaps of the low-bandgap PPVs (PM-20, PM-19, PM-18) are decreased down to 1.6 - 1.7 eV compared with that of MDMO-PPV $(2.2 \mathrm{eV})$. The best lateral hole mobility was determined to be $2.1 \times 10^{-3}$ $\mathrm{cm}^{2} / \mathrm{V}_{* \mathrm{~S}}(\mathrm{PM}-18)$ in field effect transistors and exceeds that of MDMO-PPV (poly-[2-methoxy-5-(3'.7'dimethyloctyloxy)-1.4-phenylenevinylene], $\left.8.5 \times 10^{-4} \mathrm{~cm}^{2} / \mathrm{V}_{*} \mathrm{~s}\right)$. This allows to reduce the PCBM ([6.6]phenyl- $\mathrm{C}_{61(71)}$-butanoic acid methyl ester) content in solar cell devices down to $1: 2 \mathrm{w} / \mathrm{w}$ giving a better $\eta_{\mathrm{AM} 1.5}$ than for MDMO-PPV:[60]-PCBM cells (PM-19:[60]-PCBM 2.32\% on ITO-PET, 2.86\% on ITO glass). The charge transfer to PCBM as acceptor occurs quite normally and shows an effective charge separation using light-induced spin resonance spectroscopy (LESR). The [70]-PCBM ${ }^{-}$signals are shifted to lower field related to those of [60]-PCBM ${ }^{-}$and overlap more with the polaron signal of PM-19. The LESR g-factor components of [70]-PCBM ${ }^{-}$are reported for the first time. The external quantum efficiency peak values achieve up to $42 \%$ at 350-400 $\mathrm{nm}$ and $26 \%$ at $\sim 640 \mathrm{~nm}(\mathrm{PM}-19:[60]-\mathrm{PCBM})$.
\end{abstract}

PACS. 73.61Ph Conducting polymers thin films - 84.60.Jt Photovoltaic conversion - 76.30.-v Organic materials EPR spectra

\section{Introduction}

Solar cells based on conjugated polymers can be processed from solution or dispersion which offers a very important technological potential for low-cost fabrication using high-volume processes like reel to reel technologies. One of the main reasons why the efficiency is still limited to 4-5\% [1-5] with the standard system poly(3-hexylthiophene) (P3HT):[60]-PCBM in single polymer solar cells (on glass substrates) is the low absorbance of the two components of the photoactive layer in the range of the solar spectrum combined with the necessity of a thin film thickness of this layer $(<300 \mathrm{~nm})$ restricted by the limited mobility of the charge carriers. Therefore the development of new low-bandgap polymers (LBP) whose absorption match the solar spectrum better is a key issue. Up to now only a few low-bandgap polymers gave high power conversion efficiencies in the range of 5.1-6.1\% (on glass substrates) [6-9], but the majority of such polymers typically show cell efficiencies $<1.1 \%$ (seldom $>2 \%$ ) [10] mostly linked to problems with the charge transport. Here we report about the optical, electrical and photovoltaic properties of a thieno[3.4- $b$ ]pyrazine phenylenevinylene thiophene (PM-18) and of thieno[3.4- $b$ ]pyrazine phenylenevinylene copolymers (PM-19, PM-20) related to the homopolymeric standard poly(phenylenevinylene) (PPV) (MDMO-PPV).

\section{Results and discussion}

The well-defined strictly alternating thieno[3.4- $b$ ]pyrazine-based copolymers were synthesized by Horner polycondensation route [11-12]. Figure 1 shows the chemical structures of the photoactive donor materials and the homopolymeric PPV reference (MDMO-PPV). PM-20 and PM-19 differ only in one side chain (2-ethylhexyloxy vs. noctyloxy). In PM-18 one main chain PPV ring of the monomer unit is replaced by a 3.4-dihexylthiophene moiety. [6.6]Phenyl-C $\mathrm{C}_{61(71)}$-butanoic acid methyl ester ([60]-PCBM, [70]-PCBM) were utilized as acceptors (Solenne $99.5 \%$ and 99 $\%$, respectively).

The electrochemical data for the polymers and [60]-/ [70]-PCBM obtained from cyclic voltammetry in solid state are given in Table 1. The onset and peak values for the oxidation as well as reduction of PM-20, PM-19, PM-18 are lower than those of MDMO-PPV, resulting in an energetically increased HOMO and a decreased LUMO position related to MDMO-PPV. The reduction is almost completely reversible and the oxidation only partially reversible as demonstrated in Figure 2. Figure 3 shows the optical constants of the pristine polymer films. The refractive index peak and the absorption edge of the low-bandgap PPVs are shifted to lower photon energies indicating a lower optical bandgap ( 1.6 - $1.7 \mathrm{eV})$ compared with MDMO-PPV $(\sim 2.2 \mathrm{eV})$. The absorption coefficient of the latter is larger in the spectral range of 2.3-2.9 eV. The values of the optical bandgap $\mathrm{E}_{\mathrm{g}}{ }^{\mathrm{opt}}$ were obtained by a linear extrapolation of the absorption edge as shown in the inset of Figure $3 \mathrm{~b}$. With exception of [60]-PCBM all values for $\mathrm{E}_{\mathrm{g}}{ }^{\text {opt }}$ are below those for the corresponding $\mathrm{E}_{\mathrm{g}}{ }^{\mathrm{CV}}$. The well-known discrepancy between $\mathrm{E}_{\mathrm{g}}{ }^{\mathrm{opt}}$ and $\mathrm{E}_{\mathrm{g}}{ }^{\mathrm{CV}}$ is still a point of discussion [13], although the 
fact is not so surprising, because the optical absorption and cyclic voltammetry are based on different energy processes contributing to the bandgap. Furthermore, the HOMO/ LUMO determination by cyclic voltammetry is a relative procedure, therefore comparable values may be obtained only at the same experimental conditions and set-up. For instance, the onset values are potentially influenced by the sweep rate or undesired background currents. Another reason for differences in $\mathrm{E}_{\mathrm{g}}{ }^{\text {opt }}$ and $\mathrm{E}_{\mathrm{g}}{ }^{\mathrm{CV}}$ could be for example, that the degree of aggregation in polymer films differs for films prepared for optical and electrochemical measurements (in our case: film preparation by spincoating vs. dropcasting, on quartz vs. platinum work electrode, from chlorobenzene vs. $\mathrm{CH}_{2} \mathrm{Cl}_{2}$,), which has possibly unequal consequences for both versions of bandgap determination.

The best lateral hole mobility was determined to be $2.1 \times 10^{-3} \mathrm{~cm}^{2} / \mathrm{V}_{* \mathrm{~S}}(\mathrm{PM}-18)$ in field effect transistors and exceeds that for MDMO-PPV $\left(8.5 \times 10^{-4} \mathrm{~cm}^{2} / \mathrm{V} * \mathrm{~s}\right)$. The on/off ratio of PM-18 transitors (on/off $\left.2 \times 10^{5}\right)$ in top contact geometry (top $\mathrm{Au}$ S/D contacts, gate: doped $\mathrm{Si}$, insulator: $\mathrm{SiO}_{2}$ ) are one order of magnitude higher than for the reference transistor with MDMO-PPV (on/off $3 \times 10^{4}$ ).

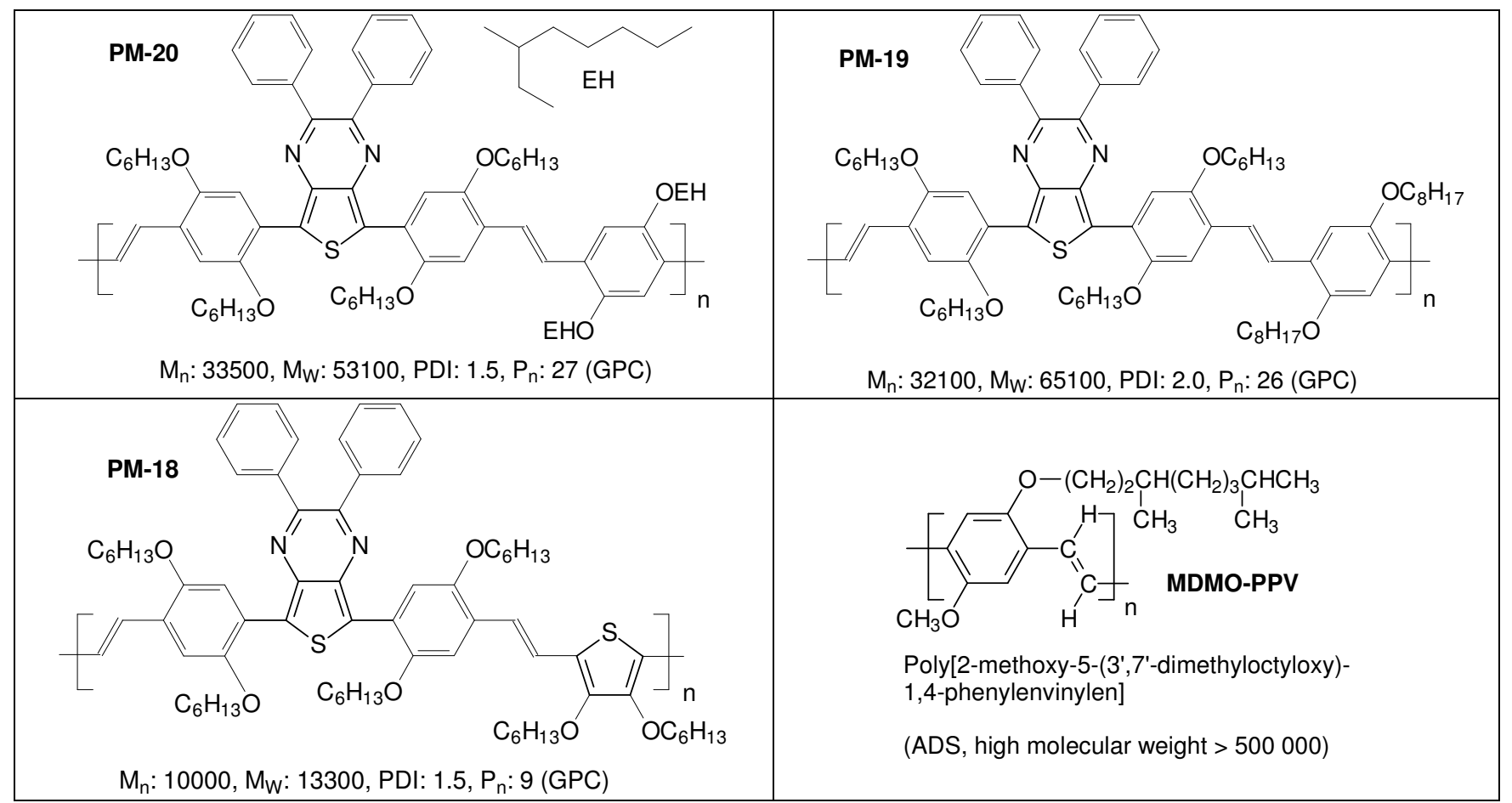

Fig.1 Chemical structure of the applied thienopyrazine-based low-bandgap poly(phenylenevinylenes) (PM-20, PM19, PM-18) in comparison to the homopolymeric standard poly(phenylenevinylene) MDMO-PPV (all function as donors in solar cells)

Tab.1 Cyclic voltammetry data (in solid state), HOMO/ LUMO levels, $\mathrm{Eg}^{\mathrm{CV}}$ and $\mathrm{Eg}^{\text {opt }}$ of the thienopyrazine-based PPVs (PM-20, PM-19, PM-18) compared with the standard MDMO-PPV

\begin{tabular}{|c|c|c|c|c|c|c|c|c|}
\hline Material & $\begin{array}{c}\mathrm{E}_{\mathrm{p}}{ }^{\circ \mathrm{x}} \mathrm{vs} . \\
\mathrm{Ag} / \mathrm{AgCl}\end{array}$ & $\begin{array}{l}\text { E }_{\text {onset }}^{\text {ox }} \text { vs. } \\
\text { Ag/AgCl }\end{array}$ & $\begin{array}{c}\text { HOMO } \\
{[\mathrm{eV}]}\end{array}$ & $\begin{array}{l}\mathrm{E}_{\mathrm{p}}^{\mathrm{red}} \mathrm{vs} . \\
\mathrm{Ag} / \mathrm{AgCl}\end{array}$ & $\begin{array}{c}E_{\text {onset }}^{\text {red }}{ }^{\text {vs. }} \\
\text { Ag/AgCl }\end{array}$ & $\begin{array}{c}\text { LUMO } \\
{[\mathrm{eV}]}\end{array}$ & $\begin{array}{l}\mathrm{E}_{\mathrm{g}}^{\mathrm{CV}} \\
{[\mathrm{eV}]}\end{array}$ & $\begin{array}{l}\mathbf{E}_{\mathrm{g}}^{\text {opt }} \\
{[\mathrm{eV}]}\end{array}$ \\
\hline PM-20 & $+1.15 \mathrm{~V}$ & $+0.89 \mathrm{~V}$ & -5.17 & $-1.36 \mathrm{~V}$ & $-1.17 \mathrm{~V}$ & -3.11 & 2.06 & 1.70 \\
\hline PM-19 & $+1.04 \mathrm{~V}$ & $+0.81 \mathrm{~V}$ & -5.10 & & & $-3.49^{a}$ & & 1.63 \\
\hline PM-18 & $+0.83 \mathrm{~V}$ & $+0.64 \mathrm{~V}$ & -4.93 & $-1.39 \mathrm{~V}$ & $-1.19 \mathrm{~V}$ & -3.10 & 1.83 & 1.59 \\
\hline MDMO-PPV & $+1.22 \mathrm{~V}$ & $+0.93 \mathrm{~V}$ & -5.31 & $-1.72 \mathrm{~V}$ & $-1.55 \mathrm{~V}$ & -2.83 & 2.48 & 2.17 \\
\hline [60]-PCBM & $+2.12 \mathrm{~V}$ & $+1.84 \mathrm{~V}$ & -6.12 & $-0.71 \mathrm{~V}$ & $-0.58 \mathrm{~V}$ & -3.71 & 2.41 & 2.42 \\
\hline [70]-PCBM & $+1.84 \mathrm{~V}$ & $+1.73 \mathrm{~V}$ & -6.02 & $-0.58 \mathrm{~V}$ & $-0.46 \mathrm{~V}$ & -3.83 & 2.19 & 1.75 \\
\hline
\end{tabular}

${ }^{\mathrm{a}} \mathrm{LUMO}: \mathrm{HOMO}+\mathrm{E}_{\mathrm{g}}{ }^{\text {opt }}$

$\mathrm{E}^{\mathrm{HOMO} / \mathrm{LUMO}}=\left[-\left(\mathrm{E}_{\text {onset }(\mathrm{vs} . \mathrm{Ag} / \mathrm{AgCl})}-\mathrm{E}_{\text {onset }(\mathrm{Fc} / \mathrm{Fc}+\mathrm{vs} . \mathrm{Ag} / \mathrm{AgCl})}\right)\right]-4,8 \mathrm{eV}$

three electrode cell assembly with WE: $\mathrm{Pt}, \mathrm{CE}: \mathrm{Pt}, \mathrm{RE}$ : $\mathrm{Ag} / \mathrm{AgCl}$, external standard: $\mathrm{Fc} / \mathrm{Fc}^{+}$, sweep rate: $15 \mathrm{mV} / \mathrm{s}$, supporting electrolyte: $0.1 \mathrm{~m} \mathrm{Et}_{4} \mathrm{NBF}_{4}$ (polymers) or $0.1 \mathrm{~m} \mathrm{Bu}_{4} \mathrm{NPF}_{6}$ (fullerenes) in anhydrous $\mathrm{CH}_{3} \mathrm{CN}$, sample film preparation by dropcasting on the WE from anhydrous $\mathrm{CH}_{2} \mathrm{Cl}_{2}$ followed by a drying step for 25 min at $40^{\circ} \mathrm{C}$ 


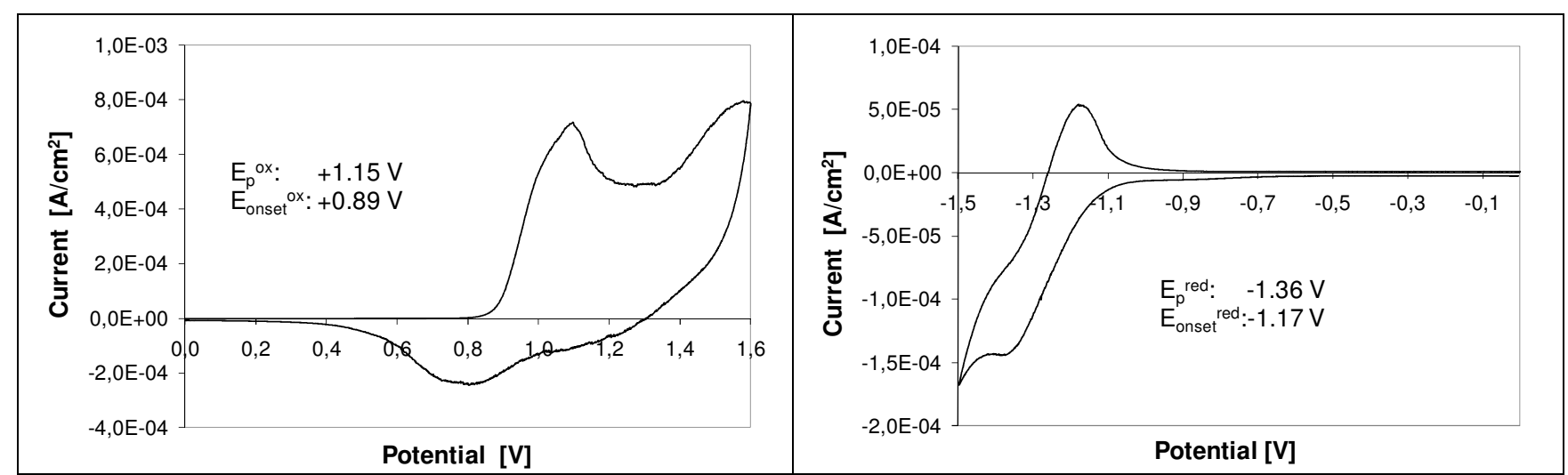

Fig.2 Cyclic voltammetric curves of PM-20 measured in solid state vs. $\mathrm{Ag} / \mathrm{AgCl}$

The charge transfer to PCBM ([6.6]-phenyl- $\mathrm{C}_{61(71)}$-butanoic acid methyl ester) as acceptor occurs quite normally, while the photoluminescence (PL) quenching factors of PM-polymer:[60]-PCBM (1:4 w/w) composite films (related to the PL of pristine polymer layers) were lower than for MDMO-PPV due to the smaller $\mathrm{LUMO}_{\text {donor }}-\mathrm{LUMO}_{\text {acceptor }}$ difference (PL factors for MDMO-PPV: 70, PM-20: 21, PM-19: 7.5, PM-18: 26.5).

Furthermore, the effective charge separation process was investigated by light-induced electron spin resonance (LESR) technique. Figure 4 shows the recorded LESR spectra of frozen solutions of pristine PM-19 $\left(\mathrm{S}_{1}\right)$, PM-19:[60]-PCBM (1:2 w/w, $\left.S_{2}\right)$, PM-19:[70]-PCBM (1:2 w/w, $S_{3}$ ) (in chlorobenzene, T: $77 \mathrm{~K}, \mathrm{CW}$ Xe-lamp illumination, X-band, 9.4 $\mathrm{GHz})$ as well as the simulated spectra for the $[70]-\mathrm{PCBM}^{-} \cdot \operatorname{radical}$ anion $\left(\mathrm{S}_{4}\right)$ and the PM-19+ ${ }^{+}$polaron $\left(\mathrm{S}_{5}\right)$. Dark signals were not observed in all three experiments. The $[70]-\mathrm{PCBM}^{-}$signals are shifted to lower field related to the spectrum of [60]-PCBM ${ }^{\bullet}$ and show more overlap with the polaron signal of PM-19 (see $S_{3}$ vs. $S_{2}$ in Figure 4). There is a significant difference between the g-factors of the [60]-PCBM ${ }^{-}$and [70]-PCBM ${ }^{\bullet}$ radical anions as well as between the electron spin relaxation dynamics. To the best of our knowledge the g-factor components of [70]-PCBM ${ }^{-}$are not $^{-P}$ reported to date $\left([70]-\mathrm{PCBM}^{-} \cdot \mathrm{g}_{\mathrm{xR}}=2.0056, \mathrm{~g}_{\mathrm{yR}}=2.0023, \mathrm{~g}_{\mathrm{zR}}=2.0022 / \mathrm{PM}-19\right.$ polaron: $\mathrm{g}_{\mathrm{xP}}=2.0037, \mathrm{~g}_{\mathrm{yP}}=2.0024$, $\mathrm{g}_{\mathrm{z}}=2.0023$ with an accuracy of \pm 0.00015$)$. The integral intensities of the separated donor and acceptor spectra (S4, S5 in Figure 4) are close to each other with an accuracy of $\sim 15 \%$ and similar to the well known P3HT:[60]-[PCBM] mixture prepared on the same conditions and weight ratio. Preliminary experiments using film samples show the same spectroscopic data but different features of the electron spin relaxation dynamics (the results will be reported later).

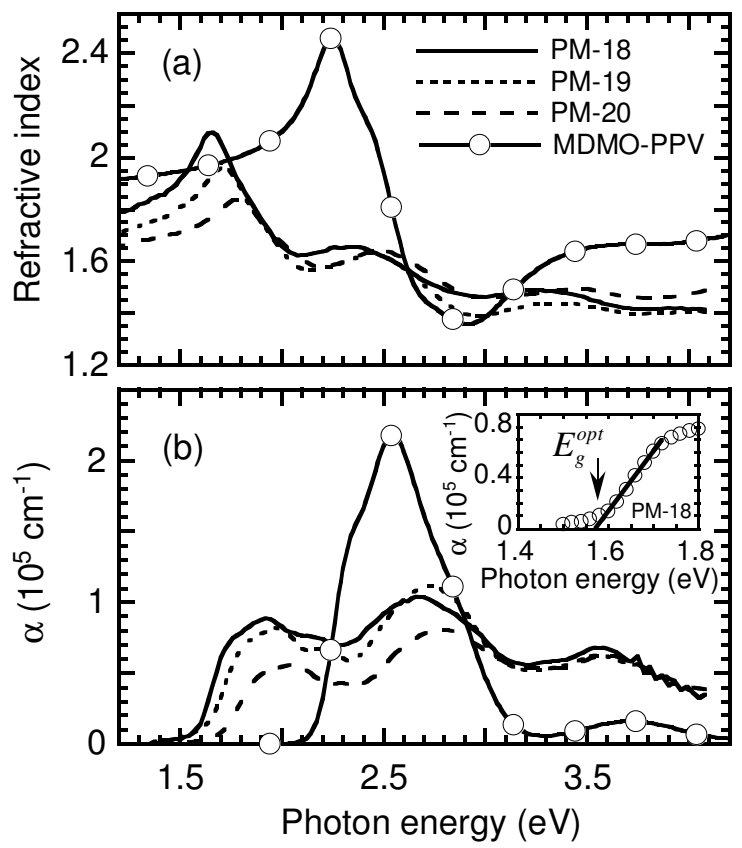

Fig.3 Refractive index (a) and absorption coefficient (b) of pristine polymer films of PM-18, PM-19 and PM-20 in comparison with the standard MDMO-PPV. The inset in (b) shows a linear extrapolation of the absorption edge which yields the optical bandgap (Table 1) 


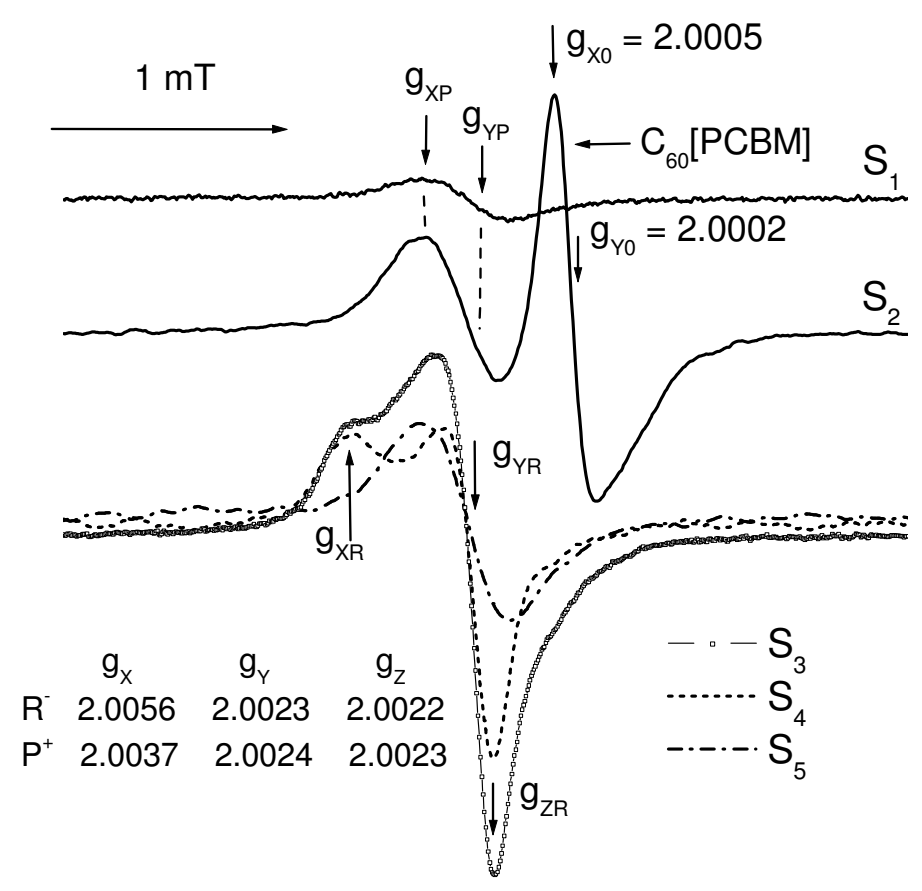

Fig.4 Recorded LESR spectra of frozen solutions of pristine PM-19 $\left(\mathrm{S}_{1}\right)$, PM-19:[60]-PCBM (1:2, $\left.\mathrm{S}_{2}\right)$, PM-19:[70]PCBM $\left(1: 2, S_{3}\right)$ (in chlorobenzene, T: $77 \mathrm{~K}, \mathrm{CW}$ Xe-lamp illumination, X-band, $\left.9.4 \mathrm{GHz}\right)$ and the simulated spectra for the $[70]-\mathrm{PCBM}^{-}$radical anion $\left(\mathrm{S}_{4}\right)$ and the $\mathrm{PM}-19^{+}$polaron $\left(\mathrm{S}_{5}\right)$

The external quantum efficiency (EQE) peak values amount to 34.0, 41.8, $34.5 \%$ for PM-20, PM-19, PM-18 blends with [60]-PCBM (1:4 w/w, Figure 5 left) and are among the best ones for low-bandgap polymers [10]. The EQE of MDMO-PPV:[60]-PCBM is in the same order of magnitude (32.8\%) but lower than in the literature ( 40\% [14], 50\% [15]) indicating a non-optimized device or MDMO-PPV batch. A lower [60]-PCBM content increases the EQE in the long wave range to $26 \%$ for PM-19 $(1: 1 \mathrm{w} / \mathrm{w})$ and to $14 \%$ for PM-18 $(1: 1 \mathrm{w} / \mathrm{w}$, Figure 5 right $)$ at $640 \mathrm{~nm}$. The comparison of PM-19 blends with [60]-PCBM vs. [70]-PCBM (1:2 w/w) gives nearly the same overall EQE but the spectrum with [70]-PCBM shows less features.

Flexible PET/ITO/PEDOT:PSS/polymer:PCBM/Al solar cells were prepared and characterized under ambient conditions (Table 2). The $\mathrm{V}_{\mathrm{OC}}$ values agree with the relative position of the HOMO polymer levels, because it is well known, that if the HOMO level is lower the $\mathrm{V}_{\mathrm{OC}}$ should be higher. Of course, this is an empirical correlation, which was advanced by Scharber et al. [16] deriving a relation between power conversion efficiency of a bulk-heterojunction solar cell, bandgap and the LUMO level of the donor. Finally, the controversy about the origin of the $\mathrm{V}_{\mathrm{OC}}$ is not definitively clarified and numerous further aspects like film morphology [17] (for instance influenced by annealing or the polymer:fullerene ratio), the electrochemical potential of the cathode [18], properties of a charge transfer state at the polymer/fullerene interface [13, 19] or energetic disorder of the electronic density of states of acceptor and donor materials [20] play a role.

The variation of polymer:[60]-PCBM ratio for PM-19 and PM-18 gives the best $\eta_{\text {AM1.5 }}$ for a 1:2 w/w ratio (for PM-19 $2.32 \%$ on ITO polyester, $2.86 \%$ on ITO glass, Figure 6 ), which corresponds with the relatively good hole mobilities and EQE for low-bandgap polymers [10]. Substitution of [60]-PCBM by [70]-PCBM blended with PM-19 (1:2 w/w) increases the short circuit current density $\left(\mathrm{I}_{\mathrm{SC}}\right)$ due to a contribution of [70]-PCBM to the light absorption based on its smaller optical gap than [60]-PCBM, but the power conversion efficiency remains nearly the same. 


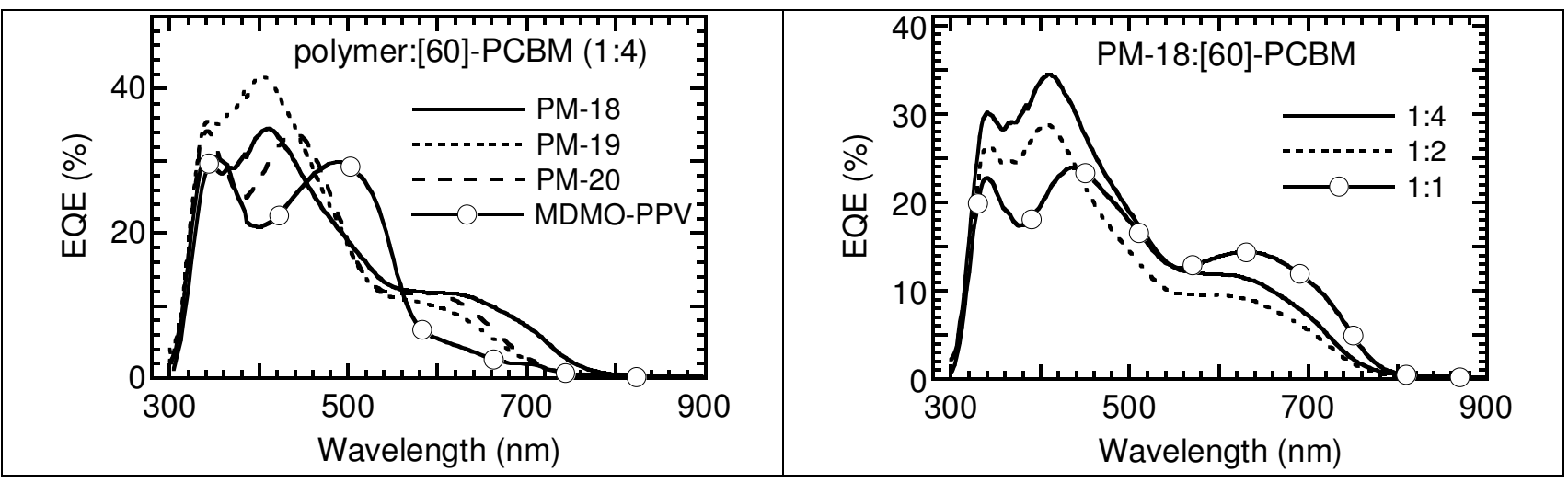

Fig.5 External quantum efficiency (EQE) of polymer:[60]-PCBM (1:4 w/w) solar cell devices (left) and the effect of the PCBM content on the EQE of PM-18:[60]-PCBM devices (right)

Tab.2 Photovoltaic parameters of flexible ITO/PEDOT:PSS/polymer:fullerene/Al solar cells based on low-bandgap PPVs (PM-20, PM-19, PM-18):PCBM compared with MDMO-PPV:PCBM devices under illumination with $100 \mathrm{~mW} / \mathrm{cm}^{2}$ of AM1.5 white light (on ITO-PET/ Cadillac Plastics, $60 \Omega /$, A: $25 \mathrm{~mm}^{2}$, Steuernagel solar simulator)

\begin{tabular}{cclll}
\hline \hline Active layer $(\mathbf{w} / \mathbf{w})$ & $\mathbf{I}_{\mathbf{S C}}\left[\mathbf{m A} / \mathbf{c m}^{2}\right]$ & $\mathbf{V}_{\mathbf{O C}}[\mathbf{m V}]$ & $\mathbf{F F}$ & $\eta_{\text {AM1.5 }}[\%]$ \\
\hline MDMO-PPV/[60]-PCBM (1:4) & 4.58 & 823 & 0.53 & 2.00 \\
MDMO-PPV/[60]-PCBM (1:3) & 3.78 & 831 & 0.53 & 1.67 \\
MDMO-PPV/[60]-PCBM (1:1) & 1.06 & 791 & 0.38 & 0.32 \\
\hline PM-20/[60]-PCBM (1:4) & 4.51 & 764 & 0.51 & 1.76 \\
PM-20/[60]-PCBM (1:3) & 3.86 & 754 & 0.47 & 1.36 \\
\hline PM-19/[60]-PCBM (1:4) & 4.18 & 656 & 0.46 & 1.27 \\
PM-19/[60]-PCBM (1:3) & 4.72 & 612 & 0.53 & 1.54 \\
PM-19/[60]-PCBM (1:2) & 6.20 & 584 & 0.64 & 2.32 \\
PM-19/[60]-PCBM (1:2)* & 7.71 & 553 & 0.67 & 2.86 \\
PM-19/[60]-PCBM (1:1) & 6.79 & 601 & 0.45 & 1.84 \\
\hline PM-19/[70]-PCBM (1:2) & 7.40 & 606 & 0.53 & 2.38 \\
PM-19/[70]-PCBM (1:2)* & 8.24 & 564 & 0.61 & 2.84 \\
\hline PM-18/[60]-PCBM (1:4) & 3.93 & 564 & 0.47 & 1.04 \\
PM-18/[60]-PCBM (1:3) & 3.96 & 580 & 0.46 & 1.05 \\
PM-18/[60]-PCBM (1:2) & 4.42 & 576 & 0.53 & 1.34 \\
PM-18/[60]-PCBM (1:1) & 3.79 & 581 & 0.54 & 1.19 \\
\hline \hline
\end{tabular}

* reference device on ITO glass (Merck Displays, $13 \Omega / \quad$ )

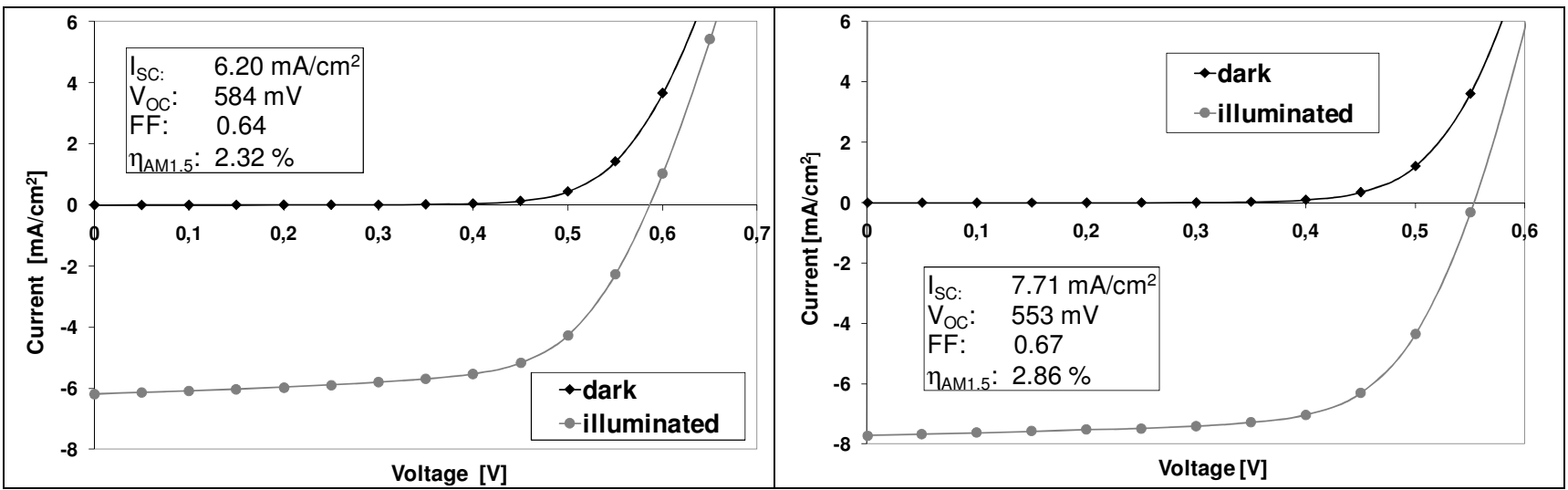

Fig.6 Current-voltage characteristics of PM-19:[60]-PCBM (1:2 w/w) polymer solar cells on ITO polyester (60 $\Omega /$, left) and ITO glass substrates $(13 \Omega /$, right $)\left(\mathrm{A}: 25 \mathrm{~mm}^{2}, \mathrm{P}_{\mathrm{IN}}: 100 \mathrm{~mW} / \mathrm{cm}^{2}\right.$ of AM1.5 white light)

\section{Conclusion}

We demonstrate by PL and LESR that thienopyrazine-based low-bandgap PPVs blended with PCBM as acceptor show an effective charge transfer as well as exhibit a higher lateral hole mobility than the reference MDMO-PPV. This allows to reduce the PCBM content in solar cell devices down to $1: 2 \mathrm{w} / \mathrm{w}$ giving a better $\eta_{\mathrm{AM} 1.5}$ than for MDMO-PPV:[60]PCBM cells (PM-19:[60]-PCBM 2.32\% on ITO-PET, 2.86\% on ITO glass). The EQE peak values amount up to $42 \%$ 
for PM-19:[60]-PCBM and are among the best ones for low-bandgap polymers [10]. The comparison of [60]- and [70]PCBM blended with PM-19 (1:2 w/w) gives a higher $\mathrm{I}_{\mathrm{SC}}$ but similar cell efficiencies. The LESR g-factor components of $[70]-\mathrm{PCBM}^{-}$are reported for the first time.

\section{Acknowledgement}

Financial support from the Thuringian Ministry for Economics, Technology and Employment (project 2006 WF 0068) is gratefully acknowledged.

\section{References}

1. C.J. Brabec, J.A. Hauch, P. Schilinsky, C. Waldauf; MRS Bull. 30, 50 (2005)

2. G. Li, V. Shrotriya, J. Huang, Y. Yao, T. Moriarty, K. Emery, Y. Yang; Nature Materials 4, 864 (2005)

3. M. Reyes-Reyes, K. Kim, D. L. Carrolla; Appl. Phys. Lett. 87, 083506 (2005)

4. W. Ma, C. Yang, X. Gong, K. Lee, A. J. Heeger; Adv. Funct. Mater. 15, 1617 (2005)

5. Y. Kim, S. Cook, S.M. Tuladhar, S.A. Choulis, J. Nelson, J.R. Durrant, D.D.C. Bradley, M. Giles, I. McCulloch, C.-S. Ha, M. Ree, Nat. Mater. 5, 197 (2006)

6. J. Peet, J. Y. Kim, N. E. Coates, W. L. Ma, D. Moses, A. J. Heeger, G. C. Bazan, Nature Materials 6, 497 (2007)

7. J. K. Lee,W. L. Ma, C. J. Brabec, J. Yuen, J. S. Moon, J. Y. Kim, K. Lee, G. C. Bazan, A. J. Heeger, J. Am. Chem. Soc. 130, 3619 (2008)

8. Y. Liang, Y. Wu, D. Feng, S.-T. Tsai, H.-J. Son, G. Li, L. Yu, J. Am. Chem. Soc., 131 (1), 56 (2009)

9. S. H. Park, A. Roy, S. Beaupre', S. Cho, N. Coates, J. S. Moon, D. Moses, M. Leclerc, K. Lee, A. J. Heeger, Nature Photonics 3, 297 (2009)

10. E. Bundgaard, F. C. Krebs, Solar Energy Materials \& Solar Cells 91, 954 (2007)

11. A. Drury, S. Maier, M. Rüther, W. J. Blau, J. Mater. Chem. 13, 485 (2003)

12. M. Shahid, R. S. Ashraf, E. Klemm, S. Sensfuss, Macromolecules, Macromolecules 39, 7844 (2006)

13. S. Hellström, F. Zhang, O. Inganäs, M. R. Andersson, Dalton Trans. 2009, 10032 (2009)

14. H. Hoppe, M. Niggemann, C. Winder, J. Kraut, R. Hiesgen, A. Hinsch, D. Meissner, N. S. Sariciftci, Adv. Funct. Mater. 14, 1005 (2004)

15. C. J. Brabec, N. S. Sariciftci, J. C. Hummelen, Adv. Funct. Mater. 11, 15 (2001)

16. M. C. Scharber, D. Mühlbacher, M. Koppe, P. Denk, C. Waldauf, A. J. Heeger, C. J. Brabec, Adv. Mater. 18, 789 (2006)

17. L. Liu, Y. Shi, Y. Yang, Adv. Funct. Mater. 11, 420 (2001)

18. H. Frohne, S. E. Shaheen, C. J. Brabec, D. C. Müller, N. S. Sariciftci, K. Meerholz, Chem. Phys. Chem. 3, 795 (2002)

19. K. Tvingstedt, K. Vandewal, A. Gadisa, F. Zhang, J. Manca, O. Inganäs, J. Am. Chem. Soc. 131, 11819 (2009)

20. G. Garcia-Belmontea, J. Bisquert, Appl. Phys. Lett. 96, 113301 (2010) 